\title{
WPEYW TRAKTATU LIZBOŃSKIEGO NA REGULACJE IMIGRACYJNE UE ZE SZCZEGÓLNYM UWZGLĘDNIENIEM ZASADY SOLIDARNOŚCI I SPRAWIEDLIWEGO PODZIAEU ODPOWIEDZIALNOŚCI MIĘDZY PAŃSTWAMI CZŁONKOWSKIMI
}

ABSTRACT The influence of the Treaty of Lisbon on the EU immigration regulations with particular attention to the principle of solidarity and fair sharing of responsibility between Member States

Analysis of the influence of the Treaty of Lisbon on the EU immigration regulations with particular attention to the principle of solidarity and fair sharing of responsibility between Member States indicates that the Treaty of Lisbon extensively reformed these regulations. Its premise and mechanisms should be assessed as justified. However, they give a lot of leeway for interpretation and need to be supplemented with EU secondary law. Unfortunately, states are primarily driven by their interest when applying these rules which leads to their nonproductiveness. The recent migration crisis explicitly proves this. The reason for the above can be found, among other things, in attachment to classic understanding of state sovereignty and in the lack of the definition of solidarity principles and fair sharing of responsibility between Member States. Postulated reforms do not guarantee solving this problem either.

Key words: responsibility sharing, solidarity, immigration, Treaty of Lisbon

Słowa kluczowe: podział odpowiedzialności, solidarność, imigracja, traktat lizboński 


\section{WPROWADZENIE}

Zagadnienie będące tematem niniejszego opracowania jest tylko z pozoru dobrze poznane i jednoznaczne. Wydawać by się mogło, że skoro od wejścia w życie traktatu z Lizbony (dalej: TL) ${ }^{1}$ minęło blisko dziewięć lat, wszystkie zawarte w nim mechanizmy i rozwiązania są już wystarczająco sprawdzone i zbadane, również pod względem ich praktycznego funkcjonowania. Tymczasem okazuje się, że omawiana materia, m.in. $\mathrm{z}$ uwagi na specyfikę jej uregulowania, wciąż wymyka się jednoznacznym ocenom. Dotyczy to zresztą $\mathrm{w}$ równej mierze postrzegania zasady solidarności i sprawiedliwego podziału odpowiedzialności między państwami członkowskimi UE.

Mając powyższe na względzie, niniejsze opracowanie również nie pretenduje do tytułu kompleksowego i ujednolicającego. Wręcz przeciwnie, ma raczej na celu ukazanie różnych - obecnych w literaturze przedmiotu - konkluzji, punktów widzenia czy uwag krytycznych. Oczywiście, nie zabraknie także odautorskiego komentarza, lecz już w tym miejscu zastrzec należy, iż będzie on tylko jednym z głosów we wciąż trwającej dyskusji. Jest to bowiem zagadnienie, jak wiele innych w Unii Europejskiej, dynamiczne, zmieniające się z upływem lat i bardzo podatne na wpływ wydarzeń politycznych. Nie sposób zatem pominąć również aspektu historycznego. Wreszcie podkreślić należy, że większość dostępnej literatury przedmiotu to analizy, raporty i artykuły w mniej lub bardziej związanych z prawem Unii Europejskiej publikatorach. Oprócz potencjalnego niebezpieczeństwa nie zawsze nieskazitelnego charakteru naukowego mają one jednak ogromną zaletę - aktualność i elastyczność, jakiej brakuje zazwyczaj „poważnym” monografiom. Odzwierciedlają tym samym jedną ze specyficznych cech zagadnienia: ścisłe powiązanie $\mathrm{z}$ codziennym funkcjonowaniem tego unikalnego tworu, jakim jest Unia Europejska.

\section{UWARUNKOWANIA PRAWNE - RYS HISTORYCZNY I STAN OBECNY}

Do czasu wejścia w życie TL kwestie imigracyjne oraz azylowe państwa członkowskie ustalały między sobą głównie w drodze mniej lub bardziej formalnej współpracy. Oczywiście, istniejąca od lat 70. XX w. kooperacja zaowocowała także kilkoma konwencjami międzynarodowymi, takimi jak układ z Schengen ${ }^{2}$, Konwencja wykonawcza ${ }^{3}$ do tego

Traktat z Lizbony zmieniajacy Traktat o Unii Europejskiej $i$ Traktat ustanawiajacy Wspólnotę Europejska, sporządzony w Lizbonie dnia 13 grudnia 2007 r., Dz.U. 2009, nr 203, poz. 1569. Wszedł w życie 1 XII 2009 r., zaś w hierarchii źródeł powszechnie obowiązującego prawa Rzeczpospolitej Polskiej zgodnie z zasadą obowiązywania od chwili publikacji w Dzienniku Ustaw RP - funkcjonuje od 2 XII $2009 \mathrm{r}$.

2 Uktad między Rzadami Państw Unii Gospodarczej Beneluksu, Republiki Federalnej Niemiec oraz Republiki Francuskiej w sprawie stopniowego znoszenia kontroli na wspólnych granicach, Dz.U. UE, L 239, 22 IX 2000.

3 Konwencja Wykonawcza do uktadu z Schengen z dnia 14 czerwca 1985 roku między Rządami Państw Unii Gospodarczej Beneluksu, Republiki Federalnej Niemiec oraz Republiki Francuskiej w sprawie stopniowego znoszenia kontroli na wspólnych granicach, Dz.U. UE, L 239, 22 IX 2000. 
układu, wreszcie tzw. konwencja dublińska ${ }^{4}$. Z kolei traktat z Maastricht ${ }^{5}$ ustanawiający Unię Europejską określił zasadę współpracy międzyrządowej jako obowiązującą w obszarze wymiaru sprawiedliwości i spraw wewnętrznych. Oznaczało to, iż także w sprawach imigracyjno-azylowych niewiele postanowień będzie mieć wiążący prawnie charakter. Sytuację zmienił dopiero traktat amsterdamski ${ }^{6}$, tworząc konkretne podstawy pod wspólnotowe prawo w obu wzmiankowanych dziedzinach ${ }^{7}$, a także włączając prawny dorobek (acquis) Schengen do systemu prawa UE. Odtąd instytucje unijne mogły wreszcie sięgać po wiążące prawo wtórne, przede wszystkim dyrektywy i rozporządzenia, choć specyfika materii azylowej, imigracyjnej oraz kontroli granic wymogła daleko idące różnice w stosunku do ponadpaństwowej metody regulacji ${ }^{8}$.

Traktat z Lizbony wprowadził jednakże istotne zmiany. Przede wszystkim, opierając się w dużej mierze na uregulowaniach wcześniejszego traktatu konstytucyjnego" ${ }^{9}$ w pełni przesunął omawiane kwestie do metody ponadpaństwowej. Poszerzył równocześnie relewantne kompetencje UE, dokonując gruntownej rewizji dotąd obowiązujących regulacji. Aktualne do dziś postanowienia zawarto w art. 77-80 Traktatu o funkcjonowaniu Unii Europejskiej (TFUE $)^{10}$. Dotyczą one następujących kwestii: kontroli granicznej oraz wiz (art. 77), azylu (art. 78), imigracji (art. 79), zasady solidarności i sprawiedliwego podziału odpowiedzialności między państwami członkowskimi (art. 80). Nowa regulacja statuuje szersze, bardziej przejrzyste kompetencje Unii w sprawach Rozdziału 2 TFUE, nie tylko co do podejmowania decyzji, ale także rozszerzenia na nie kompetencji Trybunału Sprawiedliwości UE. Zwiększa efektywność decyzyjną oraz stopień harmonizacji prawa państw członkowskich w tym obszarze, zapewniając równocześnie wyższy poziom ochrony obywateli państw trzecich. Jeszcze przed wejściem w życie TL zwracano jednakże uwagę na potencjalne niebezpieczeństwa: stosunku kompetencji

4 Konwencja wyznaczajaca państwo odpowiedzialne za rozpatrywanie wniosków o azyl ztożonych $w$ jednym z Państw Cztonkowskich Wspólnot Europejskich, sporządzona w Dublinie dnia 15 czerwca 1990 r., Dz.U. 2005, nr 24, poz. 194.

5 Traktat o Unii Europejskiej, Dz.U. 2004, nr 90, poz. 864/30 z późn. zm.

6 Traktat z Amsterdamu zmieniający traktat o Unii Europejskiej, traktaty ustanawiające Wspólnoty Europejskie i niektóre zwiąane z nimi akty, Dz.U. 2004, nr 90, poz. 864/31 z późn. zm.

7 Kilka państw członkowskich skorzystało wówczas z klauzuli opt-out; należą do nich Wielka Brytania, Irlandia i Dania.

8 Trudno się temu dziwić, skoro sprawy te od zawsze należały i wciąż należą do zakresu uznawanego przez państwa za ściśle związany z ich suwerennością. Ma to swoje odzwierciedlenie także w rozumieniu i stosowaniu zasady solidarności, o czym dalej.

$9 \quad$ Traktat ustanawiający Konstytucję dla Europy, Dz.U. UE, C 310, 16 XII 2004.

10 Treść przepisów została wzięta z: Wersje skonsolidowane Traktatu o Unii Europejskiej i Traktatu o funkcjonowaniu Unii Europejskiej - Traktat o Unii Europejskiej (wersja skonsolidowana) - Traktat o funkcjonowaniu Unii Europejskiej (wersja skonsolidowana) - Protokoty - Zataczniki - Deklaracje dotaczone do Aktu końcowego konferencji międzyrządowej, która przyjęta Traktat z Lizbony podpisany $w$ dniu 13 grudnia 2007 roku - Tabele ekwiwalencyjne, Dz.U. UE, C 326, 26 X 2012. Art. 77-80 TFUE tworzą razem Rozdział 2 „Polityki dotyczące kontroli granicznej, azylu i imigracji”. Zob. K. Hailbronner, D. Thym, Constitutional Framework and Principles for Interpretation, [w:] EU Immigration and Asylum Law. Commentary, red. ciż, München 2016, s. 1 i nast. 
UE w sprawach migracji do innych postanowień prawa (np. umów międzynarodowych) oraz problem dokładnego określenia granic działania UE odnośnie do wyznaczania limitów (kwot) migracyjnych; mowa przede wszystkim o migracji ekonomicznej. Należy się zgodzić, że spory te mają charakter głównie polityczny i wskazują na zdolność instytucji unijnych (lub jej brak) do takiej harmonizacji prawa państw członkowskich, która zapewni wysoki poziom ochrony migrantów ${ }^{11}$.

\section{ZASADA SOLIDARNOŚCI I SPRAWIEDLIWEGO PODZIAEU ODPOWIEDZIALNOŚCI MIĘDZY PAŃSTWAMI CZŁONKOWSKIMI}

Tytułowa klauzula wydaje się szczególnie interesującym, ale i kontrowersyjnym elementem regulacji Rozdziału 2 TFUE. Zgodnie z brzmieniem art. 80 TFUE Polityki Unii, o których mowa w niniejszym rozdziale, oraz ich wprowadzanie w życie podlegają zasadzie solidarności i sprawiedliwego podziatu odpowiedzialności między Państwami Cztonkowskimi, w tym również na ptaszczyźnie finansowej. Akty Unii przyjęte na podstawie niniejszego rozdziatu zawieraja, w każdym niezbędnym przypadku, odpowiednie środki $w$ celu zastosowania tej zasady. Warto zauważyć, że od czasu wejścia w życie TL zasada solidarności sensu largo przewija się przez prawo pierwotne UE, w różnym kontekście i ujęciach ${ }^{12}$;

11 Tak S. Peers, Legislative Update: EU Immigration and Asylum Competence and Decision-Making in the Treaty of Lisbon, „European Journal of Migration and Law” 2008, vol. 10, nr 2, s. 247, [online] https:// doi.org/10.1163/157181608X317354. Zob. także S. Angenendt, R. Parkes, EU-Migrationspolitik nach Lissabon und Stockholm. Neue Kompetenzen, bessere Politik?, SWP-Aktuell 71, Berlin 2009, s. 1-4; G. Fitchew, The Lisbon European Reform Treaty Impact on Asylum and Immigration Policy, European Union: MW 82, Migration Watch UK, 14 III 2008, [online] https://www.migrationwatchuk.org/ briefing-paper/82, 14 IV 2018; L. Roots, The Impact of the Lisbon Treaty on the Development of EU Immigration Legislation, „Croatian Yearbook of European Law and Policy” 2009, vol. 5, s. 261 i nast.

12 Jak podaje jeden z komentatorów: Stata się ona jedna z zasad wspótpracy cztonków UE w trzech obszarach materialnych: $w$ sferze polityki gospodarczej państw, gdzie pozwala Unii Europejskiej na interwencje $w$ rynkowe zasady funkcjonowania, poprzez podjęcie, w sytuacji kryzysowej, stosownych środków wspierajacych lub udzielenie zwrotnej lub bezzwrotnej pomocy finansowej (art. 122 TFUE); w dziedzinie polityki energetycznej, gdzie na wniosek delegacji polskiej nakazano prowadzić ja "w duchu solidarności między Państwami Cztonkowskimi" (art. 122 ust. 1 TFUE oraz art. 194 ust. 1 TFUE); w sferze spraw wewnętrznych, tworzac obowiązek wspótpracy między państwami cztonkowskim „w duchu solidarności", jeżeli jedno z nich statoby sięprzedmiotem ataku terrorystycznego lub klęski żywiotowej, bądź katastrofy spowodowanej przez cztowieka (art. 222 TFUE). Dodatkowo zasada solidarności stanowi fundament dla polityki bezpieczeństwa UE poprzez stworzenie gwarancji w ramach tzw. klauzuli sojuszniczej, w myśl której państwa cztonkowskie zobowiązane sa do udzielenia „pomocy i wsparcia przy zastosowaniu wszelkich dostępnych środków” temu państwu cztonkowskiemu, które "stanie się ofiara agresji na jego terytorium" (art. 42 ust. 7 TUE). Czasem też, choć tu chyba przesadnie, apeluje się, aby w duchu solidarności interpretować trzy obowiąki państw cztonkowskich w ramach Wspólnej Polityki Zagranicznej UE. Chodzi tu o: obowiąek uzgadniania wszelkich spraw stanowiacych tzw. przedmiot ogólnego zainteresowania w celu określenia wspólnego podejścia (art. 32 TUE), obowiązek konsultacji przed podjęciem jakichkolwiek dziatań na arenie międzynarodowej lub przed zaciagnięciem wszelkich zobowiazań, jeśli mogtyby one wptynać na interesy Unii (art. 32 TUE), obowiazek koordynacji dziatań na forum organizacji międzynarodowych i na konferencjach międzynarodowych dla podtrzymania stanowiska UE (art. 34 TUE) - M. Muszyński, Europejska solidarność - obowiązek czy akt woli politycznej?, Ośrodek 
sama idea nie wywodzi się jednak z TL, lecz obecna jest od początku integracji europejskiej ${ }^{13}$.

Bez wątpienia zasada solidarności dotyczy wszystkich spraw objętych Rozdziałem 2 i odnosi się zarówno do państw członkowskich, jak i instytucji unijnych. Nie wyklucza to jednak sytuacji, gdy środki stosowane przez państwa członkowskie, inne niż wprost wynikające ze stosowania (implementacji) prawa UE, będą stały w sprzeczności z nią (oraz zasadą sprawiedliwego podziału odpowiedzialności). Jest wątpliwe, czy obie te klauzule mają skutek bezpośredni; tym bardziej że nie zostały doprecyzowane w traktatach. Wynikają stąd różne możliwości ich interpretacji. Przyjmując punkt widzenia państwa członkowskiego, zasada sprawiedliwego podziału odpowiedzialności opierać się będzie na kryterium „słuszności” czy „uczciwości”, a to z kolei definiowane jest przez potrzeby (interesy) tego państwa. Podejście takie niekoniecznie musi odpowiadać postrzeganiu unijnemu, a nawet może być sprzeczne z celami UE. Wzywając do wspólnego działania w celu uszczelnienia granic na potrzeby np. postępowania azylowego, państwa członkowskie nie będą się raczej poczuwać do solidarności, jeśli liczba ubiegających się o status uchodźcy przekroczy ich oczekiwania. A zatem polityka UE dążąca do zapewnienia ochrony migrantom, azylantom i innym będącym w potrzebie obcokrajowcom łatwo może stanąć w sprzeczności z interesem państwa członkowskiego, który nakazuje ograniczanie napływu takich osób na jego terytorium. Można wprawdzie dążyć do ustalenia pewnych minimalnych poziomów solidarności i sprawiedliwego podziału odpowiedzialności, ale zawsze należy to czynić z zachowaniem zasady proporcjonalności (art. 5 ust. 4 TUE: środki wprowadzone przez UE na realizację celów postawionych przez traktaty nie mogą przekraczać granic konieczności). Sporne jest wreszcie, czy i w jakim stopniu omawiane zasady dotyczą kompetencji UE wykraczających poza art. 77-79 TFUE, tj. sytuacji, gdy działania np. w zakresie stosunków zewnętrznych dotykają kwestii azylu, imigracji i kontroli granic ${ }^{14}$.

\section{ANALIZA EFEKTYWNOŚCI REGULACJI ORAZ UWAGI KRYTYCZNE}

W literaturze przedmiotu podkreśla się, że ukształtowany przez TL system regulacji imigracyjnych wraz z zasadami solidarności i sprawiedliwego podziału odpowiedzialności nie funkcjonuje, niestety, tak efektywnie, jak zakładano przy jego konstruowaniu.

Analiz Strategicznych, 7 IX 2015, [online] https://oaspl.org/2015/09/07/europejska-solidarnosc-obowiazek-czy-akt-woli-politycznej/, 14 IV 2018. Odnośnie do tej zasady w ujęciu art. 222 TFUE warto sięgnąć do ciekawego opracowania: S. Myrdal, M. Rhinard, The European Union's Solidarity Clause: Empty Letter or Effective Tool? An Analysis of Article 222 of the Treaty on the Functioning of the European Union, UI Occasional Papers 2, Stockholm 2012, s. 1-23.

13 Zob. A. Słojewska, Podstawa Unii Europejskiej jest solidarność i odpowiedzialność, „Rzeczpospolita” 2017, 23 III, [online] http://www.rp.pl/Plus-Minus/303239916-Podstawa-Unii-Europejskiej-jest-solidarnosc-i-odpowiedzialnosc.html, 14 IV 2018.

14 Kwestie poruszane w tym rozdziale omawiają szczegółowo D. Vanheule, J. van Selm, C. Boswell, The Implementation of Article 80 TFEU - on the Principle of Solidarity and Fair Sharing of Responsibility, Including its Financial Implications, between the Member States in the Field of Border Checks, Asylum and Immigration. Study, European Parliament, Brussels 2011. 
W szczególności ostatni kryzys migracyjny dobitnie pokazał, że nie jest możliwe dalsze utrzymywanie „Europy bez granic” w obecnym kształcie, jeśli państwa członkowskie będą postępowały, kierując się głównie własnym interesem. Zdaje się to bowiem nie do pogodzenia z celami i zasadami omawianego systemu, w szczególności z zasadą sprawiedliwego podziału odpowiedzialności. Ma ona charakter nadrzędny względem prawa krajowego i wszelkie decyzje w sprawach migracji muszą być z nią zgodne (oraz z innymi zobowiązaniami państw, wynikającymi z prawa międzynarodowego i unijnego $)^{15}$. Ponadto reguła pierwszego kontaktu (pierwszy kraj UE, do którego dotarł imigrant czy uchodźca spoza Unii, jest odpowiedzialny za przyjęcie jego wniosku o nadanie statusu uchodźcy) powoduje, że państwa chętnie się nią zasłaniają, aby uciec od swojej części odpowiedzialności. Taka postawa opiera się też na poczuciu własnej suwerenności, co m.in. doprowadziło do faktycznego rozpadu tzw. system dubliński ${ }^{16}$. Postuluje się zatem m.in., aby dążyć do „eksternalizacji” ochrony migrantów, czego przykładem może być porozumienie UE-Turcja. Rozwiązanie takie ułatwiałoby osiąganie konsensusu między państwami członkowskimi, nie naruszając ich suwerenności ${ }^{17}$.

Jednakże nawet ostatnie orzecznictwo Trybunału Sprawiedliwości UE wskazuje, iż problem migracji jest obciążeniem przede wszystkim dla państw, których granice pokrywają się z zewnętrzną granicą UE ${ }^{18}$. Dotyczy to obecnie przede wszystkim Włoch, które (zgodnie z rozporządzeniem Dublin III) są odpowiedzialne za rozpatrywanie wniosków o azyl napływających do nich uchodźców. Natomiast państwa, takie jak Niemcy, Francja czy Austria, same decydują, czy i w jakim zakresie udzielą im pomocy.

Dlatego stwierdzić można, że skoro w polityce migracyjnej nie ma de facto wspólnoty wartości i interesów, zorientowane na nią de iure mechanizmy unijne muszą zawodzić. Nie są bowiem przygotowane na to, że państwa konsekwentnie odmawiają współpracy ${ }^{19}$. Jako dowód wskazuje się m.in. postępowanie członków Grupy Wyszehradzkiej (Czechy, Węgry, Polska, Słowacja). Zdaniem niektórych autorów ich obiekcje

15 Tak E. Küçük, The Principle of Solidarity and Fairness in Sharing Responsibility: More than Window Dressing?, „European Law Journal” 2016, vol. 22, nr 4, s. 468, [online] https://doi.org/10.1111/ eulj.12185.

16 Obecnie w postaci Rozporządzenia Dublin III - Rozporzadzenie Parlamentu Europejskiego i Rady (UE) nr 604/2013 z dnia 26 czerwca 2013 r. w sprawie ustanowienia kryteriów i mechanizmów ustalania państwa cztonkowskiego odpowiedzialnego za rozpatrzenie wniosku o udzielenie ochrony międzynarodowej ztożonego w jednym z państw cztonkowskich przez obywatela państwa trzeciego lub bezpaństwowca, Dz.U. UE, L 180, 29 VI 2013.

17 C. Roos, Souveränität oder Solidarität? Die Reformbemühungen um das krisenhafte EU-Grenzregime, [w:] FluchtMigration und gesellschaftliche Transformationsprozesse. Transdisziplinare Perspektiven, red. S. Goebel i in., Wiesbaden 2018, s. 38.

18 Wyrok Trybunału (wielka izba) z dnia 26 VII 2017 r. (wniosek o wydanie orzeczenia w trybie prejudycjalnym złożony przez Vrhovno sodišče Republike Slovenije - Słowenia) - A.S. / Republika Slovenija (sprawa C-490/16) oraz Wyrok Trybunału (wielka izba) z dnia 26 VII 2017 r. (wniosek o wydanie orzeczenia w trybie prejudycjalnym złożony przez Verwaltungsgerichtshof - Austria) - postępowanie wszczęte przez Khadiję Jafari, Zainab Jafari (sprawa C-646/16).

19 M. Becker, Solidarität mit Flüchtlingen? Euer Problem!, „Der Spiegel” 2017, 26 VII, [online] http:// www.spiegel.de/politik/ausland/fluechtlinge-europaeischer-gerichtshof-staerkt-dublin-verordnung-zum-asylrecht-a-1159810.html, 14 IV 2018. 
co do przyjmowania imigrantów oraz niechęć do brania na siebie obowiązków wynikających z zasady sprawiedliwego podziału odpowiedzialności niweczą także wysiłki tych państw członkowskich, które poszukują wspólnych, unijnych rozwiązań opartych na lojalnej współpracy i solidarności. W ich przypadku powoływanie się na odpowiedzialność i konieczność ochrony granic zewnętrznych prowadzić miałoby do faktycznego przesunięcia punktu ciężkości z podziału odpowiedzialności wspólnej na, wspomnianą już wyżej, eksternalizację oraz działanie w „kraju problemu” (vide Libia) ${ }^{20}$.

Jako konkluzję można zatem przyjąć, że ukształtowane przez TL, a znajdujące się obecnie w Rozdziale 2 TFUE regulacje imigracyjne - choć słuszne i spójne - nie spełniają pokładanych w nich oczekiwań względem praktycznej efektywności. Wielokrotnie podkreślana przez TL solidarność, będąca przecież zasadą całego systemu UE, jest wprawdzie postrzegana jako istotna wartość, lecz jej rozumienie i zakres bardzo różnią się w interpretacjach oraz postępowaniu państw członkowskich. To samo można powiedzieć o klauzuli sprawiedliwego podziału odpowiedzialności ${ }^{21}$. Być może trzeba, jakkolwiek niechętnie, zgodzić się z następującą opinią: Wtaściwie w obecnym stanie prawnym tylko raz mogliśmy obejrzeć zewnętrzne przejawy solidarności unijnej. Podkreślmy - zewnętrzne przejawy, a nie jej rzeczywista realizację. Chodzi tu o groźbę bankructwa Grecji. Państwa UE podjety w 2011 r. dziatania pomocowe, przekraczajac nawet swe uprawnienia wynikajace z konkretnej normy traktatowej. Jednak nie kierowata nimi solidarność, ale strach przed rozlaniem się kryzysu na wtasne terytoria [...]. To wszystko zawraca nas do punktu wyjścia. Pokazuje, że solidarność w polityce międzynarodowej postrzegana jako reguta tej polityki, ciagle jeszcze nie istnieje. Stata sie jedynie nowym instrumentem, przykrywka dla realizacji interesu narodowego pod nośnymi hastami ${ }^{22}$.

\section{BIBLIOGRAFIA}

Angenendt S., Parkes R., EU-Migrationspolitik nach Lissabon und Stockholm. Neue Kompetenzen, bessere Politik?, SWP-Aktuell 71, Berlin 2009.

Becker M., Solidarität mit Flüchtlingen? Euer Problem!, „Der Spiegel” 2017, 26 VII, [online] http://www.spiegel.de/politik/ausland/fluechtlinge-europaeischer-gerichtshof-staerkt-dublin-verordnung-zum-asylrecht-a-1159810.html.

Fitchew G., The Lisbon European Reform Treaty Impact on Asylum and Immigration Policy, European Union: MW 82, Migration Watch UK, 14 III 2008, [online] https://www.migrationwatchuk.org/briefing-paper/82.

Goldner Lang I., Is There Solidarity on Asylum and Migration in the EU?, „Croatian Yearbook of European Law and Policy" 2013, vol. 9.

20 Tak B. Nagy, Sharing the Responsibility or Shifting the Focus? The Responses of the EU and the Visegrad Countries to the Post-2015 Arrival of Migrants and Refugees, „Global Turkey in Europe” Working Paper 17, Roma 2017, s. 15-16.

21 I. Goldner Lang, Is There Solidarity on Asylum and Migration in the EU?, „Croatian Yearbook of European Law and Policy" 2013, vol. 9, s. 12-14.

22 M. Muszyński, Europejska solidarność..., s. 8. 
Hailbronner K., Thym D., Constitutional Framework and Principles for Interpretation, [w:] EU Immigration and Asylum Law. Commentary, red. ciż, München 2016.

Küçük E., The Principle of Solidarity and Fairness in Sharing Responsibility: More than Window Dressing?, „European Law Journal” 2016, vol. 22, nr 4, [online] https://doi.org/10.1111/ eulj.12185.

Muszyński M., Europejska solidarność - obowiazek czy akt woli politycznej?, Ośrodek Analiz Strategicznych, 7 IX 2015, [online] https://oaspl.org/2015/09/07/ europejska-solidarnosc-obowiazek-czy-akt-woli-politycznej/.

Myrdal S., Rhinard M., The European Union's Solidarity Clause: Empty Letter or Effective Tool? An Analysis of Article 222 of the Treaty on the Functioning of the European Union, UI Occasional Papers 2, Stockholm 2012.

Nagy B., Sharing the Responsibility or Shifting the Focus? The Responses of the EU and the Visegrad Countries to the Post-2015 Arrival of Migrants and Refugees, "Global Turkey in Europe” Working Paper 17, Roma 2017.

Peers S., Legislative Update: EU Immigration and Asylum Competence and Decision-Making in the Treaty of Lisbon, „European Journal of Migration and Law” 2008, vol. 10, nr 2, [online] https://doi.org/10.1163/157181608X317354.

Roos C., Souveränität oder Solidarität? Die Reformbemühungen um das krisenhafte EU-Grenzregime, [w:] FluchtMigration und gesellschaftliche Transformationsprozesse. Transdisziplinare Perspektiven, red. S. Goebel [i in.], Wiesbaden 2018.

Roots L., The Impact of the Lisbon Treaty on the Development of EU Immigration Legislation, „Croatian Yearbook of European Law and Policy” 2009, vol. 5.

Słojewska A., Podstawa Unii Europejskiej jest solidarność i odpowiedzialność, „Rzeczpospolita” 2017, 23 III, [online] http://www.rp.pl/Plus-Minus/303239916-Podstawa-Unii-Europejskiej-jest-solidarnosc-i-odpowiedzialnosc.html.

Vanheule D., Selm J. van, Boswell C., The Implementation of Article 80 TFEU - on the Principle of Solidarity and Fair Sharing of Responsibility, Including its Financial Implications, between the Member States in the Field of Border Checks, Asylum and Immigration. Study, European Parliament, Brussels 2011.

\section{Akty prawne}

Konwencja Wykonawcza do uktadu z Schengen z dnia 14 czerwca 1985 roku między Rzadami Państw Unii Gospodarczej Beneluksu, Republiki Federalnej Niemiec oraz Republiki Francuskiej w sprawie stopniowego znoszenia kontroli na wspólnych granicach, Dz.U. UE, L 239, 22 IX 2000.

Konwencja wyznaczająca państwo odpowiedzialne za rozpatrywanie wniosków o azyl ztożonych w jednym z Państw Cztonkowskich Wspólnot Europejskich, sporządzona w Dublinie dnia 15 czerwca 1990 r., Dz.U. 2005, nr 24, poz. 194.

Rozporzadzenie Parlamentu Europejskiego i Rady (UE) nr 604/2013 z dnia 26 czerwca 2013 r. w sprawie ustanowienia kryteriów i mechanizmów ustalania państwa cztonkowskiego odpowiedzialnego za rozpatrzenie wniosku o udzielenie ochrony międzynarodowej ztożonego w jednym z państw cztonkowskich przez obywatela państwa trzeciego lub bezpaństwowca, Dz.U. UE, L 180, 29 VI 2013. 
Traktat o Unii Europejskiej, Dz.U. 2004, nr 90, poz. 864/30 z późn. zm.

Traktat ustanawiający Konstytucję dla Europy, Dz.U. UE, C 310, 16 XII 2004.

Traktat z Amsterdamu zmieniajacy traktat o Unii Europejskiej, traktaty ustanawiajace Wspólnoty Europejskie i niektóre zwiąane z nimi akty, Dz.U. 2004, nr 90, poz. 864/31 z późn. zm.

Traktat z Lizbony zmieniający Traktat o Unii Europejskiej i Traktat ustanawiajacy Wspólnotę Europejska, sporzadzony w Lizbonie dnia 13 grudnia 2007 r., Dz.U. 2009, nr 203, poz. 1569.

Uktad między Rzadami Państw Unii Gospodarczej Beneluksu, Republiki Federalnej Niemiec oraz Republiki Francuskiej w sprawie stopniowego znoszenia kontroli na wspólnych granicach, Dz.U. UE, L 239, 22 IX 2000.

Wersje skonsolidowane Traktatu o Unii Europejskiej i Traktatu o funkcjonowaniu Unii Europejskiej - Traktat o Unii Europejskiej (wersja skonsolidowana) - Traktat o funkcjonowaniu Unii Europejskiej (wersja skonsolidowana) - Protokoty - Zataczniki - Deklaracje dotaczone do Aktu końcowego konferencji międzyrządowej, która przyjęta Traktat z Lizbony podpisany w dniu 13 grudnia 2007 roku - Tabele ekwiwalencyjne, Dz.U. UE, C 326, 26 X 2012.

Dr Krzysztof ZAŁUCKI, LL.M. Eur. (München), zajmuje się problematyką Unii Europejskiej, stosunków międzynarodowych, zagadnieniami polskiego i międzynarodowego prawa handlowego i gospodarczego. Posiada szeroką znajomość prawa europejskiego i międzynarodowego publicznego. Doktor nauk prawnych Wydziału Prawa, Administracji i Ekonomii Uniwersytetu Wrocławskiego (WPAiE UWr). Magister europejskiego i międzynarodowego prawa gospodarczego (LL.M. Eur.) Ludwig-Maximilians-Universität w Monachium (Niemcy). Absolwent Deutsch-Polnische Rechtsschule (Szkoły Prawa Niemieckiego) organizowanej przez Humboldt-Universität w Berlinie oraz WPAiE UWr. Od października 2007 r. adiunkt na Uniwersytecie Opolskim wykładowca m.in. prawa europejskiego, międzynarodowego i prawoznawstwa. Od października 2013 r. kierownik Pracowni Prawa Międzynarodowego i Europejskiego w Katedrze Stosunków Międzynarodowych Instytutu Politologii Uniwersytetu Opolskiego. Radca prawny wpisany na listę radców prawnych OIRP we Wrocławiu. 